\title{
Effect of Learning Style on Learning Outcomes with Mediator Variable Learning Motivation
}

\section{Gumelar P. Pratama and Ani Pinayani}

Faculty of Economics and Business Education Universitas Pendidikan, Indonesia

\section{Abstract}

The learning outcomes of the economic subjects of State High Schools in Cirebon City are still low; this indicates that students in following the learning process have not been able to achieve the competencies that have been set. The low average national examination and midterm exam scores on economic subjects show that the expected learning outcomes have not been achieved. The study aims to determine the effect of student learning styles on learning outcomes in economic subjects with learning motivation as mediator variables. The research method used is an explanatory survey using a questionnaire as a data collection tool. The population in this study were

Corresponding Author: Gumelar P. Pratama gumelar@student.upi.edu

Received: 29 January 2019 Accepted: 27 February 2019 Published: 24 March 2019

Publishing services provided by Knowledge E

(c) Gumelar P. Pratama and Ani Pinayani. This article is

distributed under the terms of the Creative Commons.

Attribution License, which permits unrestricted use and redistribution provided that the original author and source are credited.

Selection and Peer-review under the responsibility of the $3 \mathrm{rd}$ ICEEBA Conference Committee. 1,036 students with a sample of 311 students using the stratified proportional random sampling technique. Data analysis techniques use path analysis. The results of the study showed that (1) Learning style had an effect on learning motivation; (2) Learning styles affect learning outcomes; (3) Learning styles affect learning outcomes through learning motivation.

Keywords: learning style, motivation, learning outcomes

\section{Introduction}

Learning outcomes are behavioral changes that occur in an individual by being marked by changes in attitudinal knowledge and skills with processes obtained from certain experiences. Thus, learning outcomes can be used as an indicator in describing the quality of human resources produced through the learning process that is organized the world of education. Data on the results of learning the average national examination (UN) of economic subjects in Cirebon City State High School.

Table 1 shows the average value of national examinations in the economic subjects of State High Schools in Cirebon City for the last three years has decreased. Then in Table 2 seen on the value of the average midterm exam was only three schools that were able to cross the minimum capability criteria (KKM) limit. 
TABLE 1: Value of National Examination for Economic Subjects of Cirebon City State High School 2014 - 2017.

\begin{tabular}{|c|c|c|c|}
\hline School & $2014 / 2015$ & $2015 / 2016$ & $2016 / 2017$ \\
\hline SMAN 1 & 59.79 & 54.79 & 57.13 \\
\hline SMAN 2 & 60.05 & 60.37 & 61.02 \\
\hline SMAN 3 & 59.77 & 59.23 & 53.57 \\
\hline SMAN 4 & 56.97 & 44.91 & 52.45 \\
\hline SMAN 5 & 56.85 & 55.08 & 46.38 \\
\hline SMAN 6 & 61.23 & 52.50 & 65.83 \\
\hline SMAN 7 & 58.47 & 61.56 & 50.60 \\
\hline SMAN 8 & 50.59 & 58.75 & 48.00 \\
\hline SMAN 9 & 52.73 & 59.46 & 47.50 \\
\hline Average & 57.38 & 56.29 & 53.61 \\
\hline
\end{tabular}

Source: Research and Development Ministry of Education and Culture (data processed).

TABLE 2: Average Value of Middle Examination Even Semester 2017/2018.

\begin{tabular}{l|l|c|c|} 
No. & School & Middle Examination & KKM \\
\hline 1 & SMAN 1 Cirebon & 73.4 & 77 \\
\hline 2 & SMAN 2 Cirebon & 78.8 & 78 \\
\hline 3 & SMAN 3 Cirebon & 72.0 & 76 \\
\hline 4 & SMAN 4 Cirebon & 78.2 & 78 \\
\hline 5 & SMAN 5 Cirebon & 75.2 & 75 \\
\hline 6 & SMAN 6 Cirebon & 73.2 & 77 \\
\hline 7 & SMAN 7 Cirebon & 71.4 & 76 \\
\hline 8 & SMAN 8 Cirebon & 70.4 & 77 \\
\hline 9 & SMAN 9 Cirebon & 71.8 & 75 \\
\hline Rata-Rata & 73.8 & 76.5 \\
Source: Research Results (data processed).
\end{tabular}

Based on Tables 1 and 2, it can be concluded that the learning outcomes of subjects in the State High School in Cirebon City are still low, this indicates that students in following the learning process have not been able to achieve the established competencies.

The low average national exam and Middle Examination scores on economic subjects show that the desired learning outcomes have not been achieved. This can also be caused by various factors that influence it, according to Gagne (in Dahar, 2011) these factors can be divided into internal and external factors. However, when viewed from the perspective of the source, the intrinsic factor actually has an important role in the learning process. One of the intrinsic factors is the learning motivation of the student. Therefore according to Uno (2010) that education must try to create an instinctive motive by growing and developing their interest in relevant fields of study. 
In addition to motivation to learn, basically the level of success in a process depends very much on the ability of each individual to implement it. Student learning styles are important aspects that must be owned by each individual or student. According to Kolb (in Ramlah, 2014) that learning style is a way that someone tends to be chosen to receive information in his environment \& process information. If each individual can manage under what conditions, where, when and how the learning style, then learning will be more effective and efficient so that learning achievement will increase.

The grand theory used in this research is Skinner's operant conditioning theory. Skinner argues that operant behavior operates in an environment without any unconditioned stimuli, Skinner's study focuses on the relationship between behavior and its consequences. According to Skinner (in Dahar, 2011) when someone is followed by pleasant consequences, that person will be more often involved in the behavior. This pleasant condition is called operant conditioning. Another example is when students prefer to learn by looking at pictures, then learning with pictures will become operant conditioning.

The pleasant conditions that these students have are implied in the conditions of their learning style. According to De Porter (2010) said that learning style is someone's way of how he absorbs, remembers, manages the information and how to think in solving problems or problems based on the student's personality. This learning style cannot immediately give effect to learning outcomes, because in the process students still need to have high learning motivation to obtain the goals. Only to achieve this goal is used learning styles that are appropriate to student behavior.

To get optimal learning outcomes, the learning process must be consciously and well organized. Hamalik (2010) states that learning is a process, an activity and not an outcome or goal. Learning is not just remembering, but wider than that, namely experiencing. The output of the learning process is learning outcomes, learning outcomes generally in the form of students' ability to understand a subject that is realized in the form of values. According to Uno (2010) explains that learning outcomes are learning experiences obtained by students in the form of certain abilities.

Some previous researchers have conducted research on learning styles and learning motivation on learning outcomes, as was done by Putri (2013), Ludji et al. (2014), Maiyetri (2014), Taiyeb (2015), Winulang (2015), Hartati (2015), Keliat (2016), Dedi et al. (2016) which that learning styles and learning motivation affect learning outcomes. However, there are also researchers like Putri (2015) which states that learning motivation does not have an effect on learning outcomes. 
Based on the description above the style and motivation of learning students have a close relationship to student learning outcomes, then the hypothesis proposed in this study are: (1) learning style influences learning motivation; (2) learning styles affect learning outcomes; (3) learning styles affect learning outcomes through learning motivation.

\section{Research Methodology}

The method used in this study is an explanatory survey method. The population in this study were students of class XI Social Sciences State High School Cirebon City as many as 1036 students. By using a stratified proportional random sampling technique obtained a sample of 311 students. The analysis model used to see the effect of independent variables on the dependent variable and to test the hypothesis will use path analysis techniques as follows:

Sub-structural equation 1:

$$
X_{2}=\beta_{0}+\beta_{1} D x_{1.1}+\beta_{2} D x_{1.2}+e_{2}
$$

Information:

$$
\begin{aligned}
& X_{2}=\text { Motivation to learn } \\
& \beta_{0}=\text { Constant } \\
& \beta_{1} \beta_{2}=\text { Path coefficient } \\
& D x_{1.1}=\text { Independent variable dummy (learning style) } \\
& D x_{1.1}=1 \text { for visual learning styles } \\
& D x_{1.1}=0 \text { for other learning styles } \\
& D x_{1.2}=\text { Independent variable dummy (learning style) } \\
& D x_{1.2}=1 \text { for auditory learning styles } \\
& D x_{1.2}=0 \text { for other learning styles } \\
& e_{2}=\text { Residual factors Learning Motivation }
\end{aligned}
$$

\section{Sub-structural equation 2}

$$
Y=\beta_{0}+\beta_{1} D x_{1.1}+\beta_{2} D x_{1.2}+\beta_{3} X_{2}+e_{1}
$$

Information: 
$Y=$ Learning Outcomes

$X_{2}=$ Motivation to learn

$\beta_{0}=$ Constant

$\beta_{1} \beta_{2} \beta_{3}=$ Path coefficient

$D x_{1.1}=$ Independent variable dummy (learning style)

$D x_{1.1}=1$ for visual learning styles

$D x_{1.1}=0$ for other learning styles

$D x_{1.2}=$ Independent variable dummy (learning style)

$D x_{1.2}=1$ for auditory learning styles

$D x_{1.2}=0$ for other learning styles

$X_{2}=$ Motivation to learn

$e_{2}=$ Residual factors Learning Motivation

\section{Result and Discussion}

\subsection{Result study}

The results of research on student learning styles are categorized into three categories of learning styles. The categorization of learning styles in class XI Social Sciences State High School Cirebon City can be seen in Table 3.

TABLE 3: Frequency distribution of student learning style state high schools in Cirebon City.

\begin{tabular}{l|l|l|c|c|c|} 
No. & Sekolah & \multicolumn{4}{|c|}{ Gaya Belajar } \\
\hline & & Visual & Auditorial & Kinestetik & \\
\hline 1 & SMAN 1 & 22 & 4 & 15 & 41 \\
\hline 2 & SMAN 3 & 13 & 17 & 40 & 70 \\
\hline 3 & SMAN 5 & 12 & 23 & 5 & 40 \\
\hline 4 & SMAN 6 & 17 & 14 & 22 & 53 \\
\hline 5 & SMAN 7 & 13 & 26 & 25 & 64 \\
\hline 6 & SMAN 9 & 10 & 18 & 15 & 43 \\
\hline
\end{tabular}

Table 3 describes in general the students of class XI Social Sciences in State High Schools throughout Cirebon City tend to have a kinesthetic learning style with as many as 122 respondents, meaning students who have a kinesthetic learning style tend to learn (1) through manipulation and practice, (2) memorizing in a way walking and seeing, 
(3) not being able to sit still for a long time, (4) working on something that allows active hands, (5) difficult to master abstract things.

TABLE 4: Frequency distribution of motivation to learn state high school students in Cirebon City.

\begin{tabular}{l|c|c|c|}
\hline Category & Range & Frequency & Percentage \\
\hline High & $\geq 33$ & 26 & 8 \\
\hline Medium & $21-32$ & 246 & 79 \\
\hline Low & $\leq 20$ & 39 & 13 \\
\hline Total & 311 & 100 \\
\hline Source: Research Results (data processed).
\end{tabular}

Table 4 explains that in general the motivation of students in class XI Social Sciences in State High Schools throughout the City of Cirebon is in the moderate category, namely 246 students with a percentage of $79 \%$, meaning that students already have good learning motivation, so this situation can support themselves in achieving learning outcomes. optimal. Learning outcomes in this study were obtained from the results of the Semester Middle Test (UTS) even semester XI Social Sciences on economic subjects in the 2017/188 academic year. The full results can be seen in Table 5

TABLE 5: Distribution of frequency of student learning outcomes in economic subjects.

\begin{tabular}{l|c|c|c|}
\hline Category & Range & Frequency & Percentage \\
\hline Tinggi & $\geq 75$ & 113 & 36 \\
\hline Sedang & $69-74$ & 119 & 38 \\
\hline Rendah & $\leq 68$ & 79 & 26 \\
\hline Total & & 311 & 100 \\
\hline Source: & &
\end{tabular}

Based on Table 5 it is known that in general student learning outcomes in economic subjects in 6 State high schools in the city of Cirebon which are the research sample are in the medium category. In the category of moderate learning outcomes, there are 119 respondents or $38 \%$. student learning in economics class XI Social Sciences in Cirebon City State High School is in the medium category.

Testing of hypotheses in this study uses path analysis. In the analysis there are two models of equations as follows:

\section{Sub-structure 1: Effect of learning styles on learning motivation (Kinesthetic Excluded Group)}

Based on Table 6, it is obtained the path coefficient value of sub-structure 1 as follows:

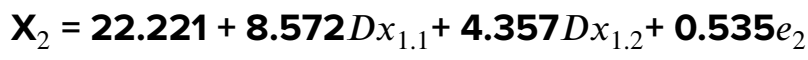


TABLE 6: Sub-structural 1 Analysis Results (Group Excluded Kinesthetic).

\begin{tabular}{|c|c|c|c|c|c|c|}
\hline \multicolumn{2}{|c|}{ Model } & \multicolumn{2}{|c|}{ Unstandardized Coefficients } & \multirow{2}{*}{$\begin{array}{c}\text { Standardized } \\
\text { Coefficients } \\
\text { Beta }\end{array}$} & \multirow[t]{2}{*}{$T$} & \multirow[t]{2}{*}{ Sig. } \\
\hline & & B & Std. Error & & & \\
\hline \multirow[t]{3}{*}{1} & (Constant) & 22.221 & 0.201 & & 110.551 & 0.000 \\
\hline & Visual & 8.572 & 0.312 & 0.933 & 27.514 & 0.000 \\
\hline & Auditorial & 4.357 & 0.298 & 0.496 & 14.628 & 0.000 \\
\hline
\end{tabular}

The results of hypothesis testing, visual learning style path coefficient values on learning motivation with $t_{\text {count }}$ value of $27.514>t_{\text {table }}$ is 1.967 with a significance value of $0.000<0.05$ then $\mathrm{H}_{0}$ is rejected and $\mathrm{Ha}$ is accepted. Then the auditory learning style path coefficient value on learning motivation with the value of $t$ calculated at 14.628 $>t$-table is 1.967 with value is $0.000<0.05$ then $\mathrm{H}_{0}$ is rejected and $\mathrm{Ha}$ is accepted, meaning that the path coefficient of the auditory learning style on learning motivation can be stated as significant. For kinesthetic learning styles are not included because the learning style is used as a basis for interpretation in the learning style category, so that without the need to do regression, motivation accompanied by kinesthetic learning styles can be identified by itself. So it can be concluded that learning styles influence learning motivation.

TABLE 7: Variable residue sub-structure 1.

\begin{tabular}{l|c|}
\hline R Square & $P \varepsilon_{1}$ \\
\hline 0.713 & 0.535 \\
\hline
\end{tabular}

Based on Table 7 it is known that the magnitude of the influence of other variables that are not contained in the sub-structure model 1 is equal to 0.535 or $53.5 \%$. After all sub-structure 1 models are tested, a diagram can be made as shown in Figure 1.

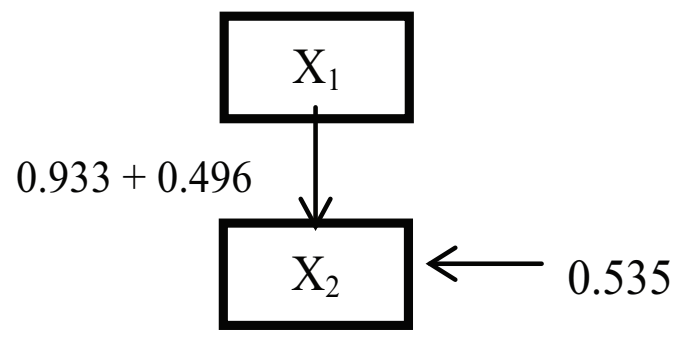

Figure 1: Model Path Analysis Sub-Structural 1. 


\section{Sub-structure 2: Effect of learning style and learning motivation on learn- ing outcomes}

Based on the results of data processing, obtained regression coefficient models and path coefficients of sub-structures 2 as shown in Table 8 .

TABLE 8: Sub-structural 2 analysis results Group Excluded Kinesthetic).

\begin{tabular}{|c|c|c|c|c|c|}
\hline \multirow[t]{2}{*}{ Model } & \multicolumn{2}{|c|}{ Unstandardized Coefficients } & \multicolumn{2}{|c|}{ Standardized Coefficients } & \multirow[t]{2}{*}{ Sig. } \\
\hline & $\mathrm{B}$ & Std. Error & Beta & $t$ & \\
\hline (Constant) & 52.897 & 1.768 & & 29.915 & 000 \\
\hline Visual & 3.730 & 0.799 & 0.322 & 4.668 & .000 \\
\hline Auditorial & 2.225 & 0.535 & 0.201 & 4.160 & 000 \\
\hline $\begin{array}{l}\text { Motivas } \\
\text { Belajar }\end{array}$ & 0.690 & 0.079 & .547 & 8.775 & 000 \\
\hline
\end{tabular}

Based on Table 8, the following path coefficient values are obtained:

$$
Y=52.897+3.730 D x_{1.1}+2.225 D x_{1.2}+0.690 X_{2}+0.585 e_{2}
$$

Based on the results of the hypothesis test, the visual learning style path coefficient on learning outcomes with a $t$-count value of $4.668>t$-table is 1.967 with a significance value of $0.000<0.05$ then $\mathrm{H}_{0}$ is rejected and $\mathrm{Ha}$ is accepted. Then the audit coefficient learning style path coefficient on learning motivation with $t$-count value of $4.160>t$ table is 1.967 with a significance value of $0.000<0.05$ then $\mathrm{H}_{0}$ is rejected and $\mathrm{Ha}$ is accepted, meaning that the learning style dummy path coefficient on learning outcomes can be stated as significant. So it can be concluded that there is an influence of learning styles on learning outcomes both directly and through learning motivation.

Furthermore, from the results of hypothesis testing, also obtained the path coefficient of learning motivation toward learning outcomes with a value of $t$-count of $8.775>t$-table is 1.649 with a significance value of $0.000<0.05$ then $\mathrm{H}_{0}$ is rejected and $\mathrm{Ha}$ is accepted, meaning that the path coefficient of learning motivation on learning outcomes can be stated as significant. So it can be concluded that there is an effect of learning motivation on learning outcomes.

TABLE 9: Residual variable sub-structure 2.

\begin{tabular}{|l|c|}
\hline R Square & $\mathbf{P} \varepsilon_{1}$ \\
\hline 0.658 & 0.585 \\
\hline
\end{tabular}

Based on Table 9 it is known that the magnitude of the influence of other variables that are not contained in the sub-structure 2 model is equal to 0.585 or $58.5 \%$. After all sub-structure 1 models are tested, a diagram can be made as shown in Figure 2 . 
Based on Table 10 it is known that the direct effect of variables $D X_{1.1}$ and $D X_{1.2}$ on $X_{2}$ is 1,429 , then for direct effects $D X_{1.1}$ and $D X_{1.2}$ on $Y$ is 0.523 , while the indirect effect is 1.304 so the total effect is 1.828 . For $X_{2}$ against $Y$ the direct effect is 0.547 .

TABLE 10: Decomposition of intervariable effects.

Intervariable Effects
$D x_{1}$ dan $D x_{2}$ terhadap $X_{2}$
$D x_{1}$ dan $D x_{2}$ terhadap $Y$
$X_{2}$ terhadap $Y$

\begin{tabular}{|c|l|}
\hline & Causal Influence \\
\hline Directly & Indirect $($ via $X 2)$ \\
\hline 1.429 & - \\
\hline 0.523 & $0.523+(1.429 \times 0.547)=1.304$ \\
\hline 0.547 & - \\
\hline
\end{tabular}

Total

1.429

1.828

0.547

\subsection{Discussion}

Based on the results of the research and testing the hypothesis it is known that simultaneously learning style dummy variables affect learning motivation, this is indicated by the $F_{\text {count }}$ value of 382,836 and $F_{\text {table }} 3,025$ (with a significant level $\alpha=0.05$ ). This shows that the learning style dummy simultaneously affects students' learning motivation in economic subjects. Furthermore, it is also known that partially learning style dummy variables affect student learning motivation in economic subjects with a visual learning style $t_{\text {count }}$ of 27,514 and $t_{\text {table }} 1,967$ (with significant level $\alpha=0.05$ ), and auditory learning style of 14,628 and $t$-table 1,967 (with a significant level $\alpha=0.05$ ). For kinesthetic learning styles not included because according to Wahyu (2010) a variable with as many categories as $\mathrm{K}$ will require a set of $\mathrm{K}-1$ dummy variables to reach all the information contained therein. Because learning styles have $3 \mathrm{~K}$, only 2 are used, namely visual and auditory learning styles, while kinesthetic learning styles become the basis for interpretation of learning style categories.

The results of research and hypothesis testing are known simultaneously there are differences in learning style dummy variables and learning motivation toward learning outcomes, this is indicated by the $\mathrm{F}_{\text {count }}$ value of 197,068 and $\mathrm{F}_{\text {table }} 3,025$ (with significant level $\alpha=0.05$ ). This shows that the learning style dummy and learning motivation have a simultaneous effect on student learning outcomes in economic subjects. Furthermore, it is also known that partially learning style dummy variables and learning motivation have an effect on student learning outcomes on economic subjects with a score of 4,668 visual learning styles, 4,160 auditory learning styles, and 8,775 learning motivation with $1,967 \mathrm{t}_{\text {tables }}$ (at significant level $\alpha=0.05$ ). 
The results of this study are in line with previous studies. Rasdjo et al. (2016) conducted a study on 108 high school students about motivational predictors in these students. Where learning style is the strongest predictor of motivation of the three predictors studied in the study. Furthermore, Taiyeb et al. (2015) studied 162 students regarding learning motivation. The results of the study show that learning styles influence learning motivation, especially intrinsic motivation.

These studies prove that learning styles can affect learning motivation. This means that if the student is able to condition his learning style well then the student will have a high learning motivation in the subjects he is studying. Based on the presentation of the results of data analysis and research findings, it can be concluded that there are differences in learning outcomes that have visual, auditory, and kinesthetic learning styles in class XI social sciences students of Cirebon City State Senior High Schools.

According to Damayanti (2016) when students use their preferred learning style students will concentrate better in learning, but when students cannot use their learning style because of an unsupportive environment, this student will have difficulty in learning. The results of this study are in line with previous studies. Putri (2013) conducted research on the influence of learning styles on learning outcomes, and the results showed the influence of learning styles on student learning outcomes. Research Febrika et al. (2015) to 88 students regarding the relationship of learning styles with learning outcomes, proving the existence of a positive relationship between the two.

The results of the sub-structure 2 study show that high learning outcomes are obtained by students who have motivation in the visual learning style, second is followed by the auditory learning style, and the last is the kinesthetic learning style. Furthermore, from the results of the study it can be seen that learning motivation affects student learning outcomes with a direct path coefficient of 0.547. Based on the explanation of the results of data analysis in research findings, the conclusion is that there is an influence of learning styles on learning outcomes through learning motivation in economic subjects.

According to the economics teacher in Cirebon City, the researchers asked about students learning styles, four of the six teachers said that visual learning styles tend to be used by students, while the rest said that it was auditory and kinesthetic learning styles that were widely used by students in class XI. This can be different because according to economics teachers, class XI students can actually do all three learning styles, it's just that the teacher continues to do the learning process that uses more learning models based on visual things so that students also tend to have a style visual learning.

The results of this study are in line with previous research, Taiyeb (2015) with respondents as many as 162 students, stating that motivation can have a positive effect on 
learning outcomes, because motivation is an important factor in efforts to improve the quality of learning. Good learning motivation will produce good learning processes and results. The higher the intensity of student learning motivation, the higher the quality and learning outcomes achieved by the student.

\section{Conclusions}

1. Learning styles affect learning motivation in economic subjects, meaning students who have a visual learning style will have high learning motivation than students who have auditory and kinesthetic learning styles.

2. Learning styles affect learning outcomes in economic subjects, meaning students who have a visual learning style will have high learning outcomes than students who have auditory and kinesthetic learning styles.

3. Learning styles affect learning outcomes through learning motivation in economic subjects, meaning that students who have a visual learning style accompanied by learning motivation will have high learning outcomes, compared to students who have auditory and kinesthetic learning styles.

\section{References}

[1] Damayanti, L. (2016). Hubungan Gaya Belajar Siswa Dengan Hasil Belajar IPS. Thesis, Universitas Negeri Semarang.

[2] Dahar, R. W. (2011). Teori-Teori Belajar dan Pembelajaran. Bandung: Erlangga.

[3] De Porter, B. (2010). Quantum Learning. Bandung: Kaifa.

[4] Febrika, E. I. (2015). Hubungan Antara Gaya Belajar Dengan Prestasi Belajar Siswa. Jurnal Pendidikan, vol. 3, no. 6, pp. 8-14.

[5] Gurria, A. (2016). PISA 2015 Result in Focus. Organisation Economic Co-operation and Development PISA Report, pp. 1-16.

[6] Hamalik, O. (2010). Kurikulum dan Pembelajaran. Jakarta: PT BumiAksara.

[7] Hartati, L. (2015). Pengaruh Gaya Belajar dan Sikap Siswa Pada Pelajaran Matematika Terhadap Hasil Belajar Matematika. Jurnal Formatif, vol. 3, no. 3, pp. 224-235.

[8] Keliat, N. R. (2016). The profile of students' learning styles and their effects on Grade Point Average (GPA) achievement. Edutech Journal, vol. 15, no. 2, pp. 188-198.

[9] Ludji, B. A., et al. (2014). Pengaruh Gaya Belajar Visual, Auditorial, Dan Kinestetik Terhadap Prestasi Belajar Siswa. Jurnal Kependidikan, vol. 44, no. 2, pp. 168-174. 
[10] Maiyetri, R. (2014). Pengaruh Gaya Belajar Visual, Gaya Belajar Auditorial, Dan Kemampuan Berpikir Kritis Terhadap Prestasi Belajar Siswa. Journal of Economic and Economic Education, vol. 2, no. 2, pp. 100-109.

[11] Putri, A. W. (2013). Pengaruh Gaya BelajarSiswa (Visual, Kinestetik, Dan Auditorial) Pada Mata Pelajaran Mengelola Peralatan Kantor Terhadap Hasil Belajar. Jurnal Administrasi Perkantoran, vol. 1, no. 3, pp. 1-21.

[12] Putri, D. T. N. (2015). Pengaruh Minat dan MotivasiTerhadap Hasil Belajar Pada Mata Pelajaran Pengantar Administrasi Perkantoran. Jurnal Pendidikan Bisnis dan Manajemen, vol. 1, no. 2, pp. 118-124.

[13] Ramlah. (2014). Pengaruh Gaya Belajar dan Keaktifan Siswa Terhadap Prestasi Belajar Matematika. Jurnal Ilmiah Solusi, vol. 1, no. 3, pp. 68-75.

[14] Rasdjo. (2016). Pengaruh Motivasi Belajar, Gaya Belajar, dan Kemandirian Belajar Terhadap Hasil Belajar Mahasiswa S1 PGSD Masukan Sarjana di UPBJJ UT Bandung. Jurnal Pendidikan Dasar, vol. 8, no. 2, pp. 163-177.

[15] Sudjana, N. (2005). Dasar-Dasar Proses Belajar Mengajar. Bandung: Sinar Baru Algesindo.

[16] Taiyeb, A. M. (2015). Hubungan Gaya Belajar dan Motivasi Belajar Dengan Hasil Belajar Biologi Siswa Kelas XI IPA SMA Negeri 1 Tanete Rilau. Jurnal Bionature, vol. 16, no. 1, pp. 8-16.

[17] Uno, H. B. (2010). Teori Motivasi dan Pengukurannya: Analisis di Bidang Pendidikan. Jakarta: PT Bumi Aksara.

[18] Wahyu, W. (2010). Prosedur Analisis Regresi dengan Variabel Dummy. Manuskrip Fakultas Psikologi. Universitas Gajah Mada.

[19] Winulang Anwar, S. (2015). Pengaruh Disiplin Belajar, Gaya Belajar dan Lingkungan Keluarga Terhadap Prestasi Belajar Mata Pelajaran Ekonomi Akuntansi. Economic Education Analysis Journal, vol. 4, no. 1, pp. 185-193. 